\title{
The Amar Chitra Katha Shakuntala: Pin-Up or Role Model?
}

\section{Nandini Chandra}

\section{(2) OpenEdition}

\section{Journals}

\section{Electronic version}

URL: http://journals.openedition.org/samaj/3050

DOI: 10.4000/samaj.3050

ISSN: 1960-6060

\section{Publisher}

Association pour la recherche sur l'Asie du Sud (ARAS)

Printed version

ISBN: 1960-6060

\section{Electronic reference}

Nandini Chandra, "The Amar Chitra Katha Shakuntala: Pin-Up or Role Model? », South Asia

Multidisciplinary Academic Journal [Online], 4| 2010, Online since 17 December 2010, connection on 19 April 2019. URL : http://journals.openedition.org/samaj/3050 ; DOI : 10.4000/samaj.3050

This text was automatically generated on 19 April 2019

\section{(c) (i) () $\Theta$}

This work is licensed under a Creative Commons Attribution-NonCommercial-NoDerivatives 4.0 International License. 


\title{
The Amar Chitra Katha Shakuntala: Pin-Up or Role Model?
}

\author{
Nandini Chandra
}

1 Amar Chitra Katha (ACK, literally 'the Immortal Illustrated Stories') comics were started by Anant Pai in 1967, under the aegis of India Book House Pvt. Limited, as an attempt to correct the colonial bias of children's literature in India. The comics were modelled on the British and American Classics Illustrated series, which mostly adapted works of fiction into comics, with a preference for the adventure tale and the exotic. The emphasis in ACK however was on the retrieval and presentation of the glorious heritage of India, usually taken to stand in for ancient India. Hindu myths, legends and classical Sanskrit texts were thus mined for evidence of a great and superior culture. Even as they collected stories from ancient sources, $A C K$ authors deployed the individual biography mode. Thus, the storyboard form in which $A C K$ adapted the various tales, legends and dramas played upon great individuals as role models, according to the established pedagogical tradition of children's literature in India, as much as the hagiographical model prevalent in premodern and early modern contexts to describe the lives of saints. The individual biography was also useful in terms of addressing a primarily English speaking upper caste, middle class child audience, for whom the bourgeois individual was the standard. The focus on the individual was thus imprinted on the narrative line, the drawing style, and the almost hegemonic appropriation of the realist ethic, seen as the only appropriate mode through which the veracity of these ancient stories could be indisputably established. In this article, I will look at the elevation of the Shakuntala story to the second title of the ACK corpus, and the implications of Shakuntala as a possible female role model in a cautionary tale about all that can go wrong if you fall for a stranger, and more disastrously consent to sleep with him, in the context of gender dynamics of the comics and the post-colonial Indian reality at large.

2 The existing comic culture in the sixties mainly consisted of foreign comics, The Phantom ${ }^{1}$ and superheroes, characterized by a sensationalist plot and a lurid imagination. UNESCO's call in 1967 to use comics as a tool for communicating cultural values provided the much 
needed thrust to Pai to start his indigenous intervention. In addition to the task of indigenizing the content, making them safe and sanitized as it were, the makers of ACK were also burdened by the comic imperative of keeping the sensationalism intact. The pedagogical force of the comics was then undeniably in tension with this need to grapple with the form of the comic itself, how to insert the educational message and remove all unsavoury associations with the market without diminishing the sensationalist plot. The subsequent production of ACKs under an educational trust, with its implicit subsidies and benevolent intentions, did help to shape the comics as separate from the western comic mode. The fact that the comics were a private initiative, and had sales ranging between one million at their peak in 1981 to 28,000 at their lowest point in 1992, when the print industry underwent a general slump, did very little to diminish their aura as a disinterested service. Its endeavours to become an effective pedagogical tool are seen, for instance, in its much publicized attempt to hold a seminar on 'The Role of Chitra Katha in School Education' in February 1978. ACK insisted that its use of the comic medium had native antecedents. The claims of having been inspired by indigenous bas reliefs at Bharhut, Sanchi and Ajanta were deemed necessary to offset any charges of western imperialism that the comic form might carry, but it also helped to project its value as a reliable guide to cultural heritage.

3 In tandem with this overall pedagogical thrust, $A C K$ inflected its narratives with signs of heroism and martyrdom. The 'Freedom Fighter' series situated in the nationalist period manifests this most prominently. But in some ways, the entire corpus of the ACK may be seen as an elaboration of this logic of heroism. Unlike the twin locus of other children's literature in the home and school, ACK narratives have an ambivalent relationship with both spaces. While schools are in urgent need of reforms, the home is seen as oppressive and restrictive. In the hagiographies of the saints for instance, the nagging mother figure will not let the child take up the life of an ascetic. In the series on the revolutionary heroes too, the mother India trope is played down, a flagrant contrast with the wider children's literary sphere, but also going against the grain of a more pervasive popular nationalist symbolism. In fact, women as satis (wives sacrificing themselves on their husbands' funeral pyre) rather than mother figures were seen to be better triggers for men to get their act together. Unless it was absolutely and historically necessary to show women in the mother mode-the various narratives of Bankim Chandra such as Devi Choudhurani and Kapala Kundala, or the figure of Jijabai in Shivaji- ACKs refrained from invoking the mother figure very liberally.

4 Perhaps the freedom imperative of the narrative, which needed the protagonist to leave both home and school in order to explore a wider world, was the reason for this toning down of the mother image. For the mystic or the freedom lover, the home was definitely oppressive. At the same time, while the serene ambience of the gurukul (the traditional school) sequestered in the lap of nature was idealized, it was not so much this association with nature that was the object of eulogy as the fact that they were places where one learned the first lessons in contending schools of scholarship. In fact, a truly great student could even learn to challenge his/her own mentor, and teach him a thing or two. The audacity needed for this kind of iconoclasm could only be honed in the training grounds of life, beyond school and home. Adventure for children was then inscribed in terms of the exposure to real brute force, necessary education for them to get on in life, rather than the artificially created safe environment of schools. 
5 How was this conflict in the pre-bourgeois world of the comics negotiated within the logic of children's literature as a field firmly entrenched in bourgeois subjectivity? The ensuing tension resulting from an ostensible display of sexualized and brutalized violence, absolutely de rigueur in children's publishing, was then sought to be cushioned by the logic of cultural relativism, which pretended that these things needed to be seen in their proper historical context, thus securing a license for what is deemed as openly inappropriate and reactionary within a modern national progressive ethos. The pressing pedagogical need to create modern role models from this historically given past however mandated more universal standards, since these historicized figures were being hailed as modern both in resonance and relevance.

\section{Female role models}

Needless to say, most of $A C K$ 's heroes were males. But $A C K$ is also characterized by an unusually substantial (for comics) presence of women as far as the sixties comics culture is concerned. Of the large number of titles devoted to women, the majority was drawn from a mythological or legendary universe, and those which were part of history were not slotted in the history series. Thus by virtue of being de-historicized, they were particularly amenable to being iconized. What was the nature of this iconicity? Were heroines meant only for the inspiration of a female readership? What kinds of ideals and aspirations did they set up for young girls reading or looking at the comics?

7 This essay will look at the Shakuntala comic, which was the second title in the series, and came out in 1971. The first one Krishna (1967) is a very obvious choice, underlining as it does the expansive and reformist Vaishnav ethic of the comics at large, through the embodiment of an intimate personal form of devotion that took the edge off the Brahminical caste and ritual ridden version of Hinduism, giving it an endearingly anthropomorphic touch in the loveable figure of the child-god Krishna. Shakuntala, coming three years after the mascot god, could only have been a very considered decision. One of the considerations could be the fact that Shakuntala is the mother of Bharata, the eponymous founder of Bharat or India. While this secondary significance of women as mothers and consorts is part of an unquestioned patriarchal dynamic in which $A C K$ is invariably steeped, it nevertheless tends to project women as individuals in their own right. As asserted before, motherhood is not very idealized in ACK. In any case, Shakuntala is hardly known for her role as a strong mother figure or as a strong figure at all. If she is an icon of something, it is that of coy femininity, a sign that ACK visuals reserve for most female protagonists, even as their more empowering characteristics are mediated through verbal signs of intelligence, smartness and character.

The eclectic adaptation from both the Hindu epic Mahabharata and the poet Kalidasa versions of the Shakuntala story sheds a little more light on her depiction in ACK. ${ }^{2}$ The need to imbue the somewhat empty damsel in distress of the Kalidasa play with the rebellion and anger of the Mahabharata heroine at least indicates that the publishers of $A C K$ are interested in the subjectivity of Shakuntala, the woman. Very briefly, while the Mahabharata story projects Shakuntala as the wronged forest woman, who is ravished by King Dushyant on his hunting sojourn and then deserted, the Kalidasa play transposes this story into an overtly romantic plot, where the king's abandonment is re-written as enforced forgetting, rationalized as the outcome of a curse incurred by Shakuntala, practically absolving him of the accusations levelled against him by the feisty 
Mahabharata Shakuntala. ${ }^{3}$ In fact, the romance proceeds precisely from the remorse and agony undergone by King Dushyant when the signet ring with which he had pledged his love to Shakuntala is recovered from the stomach of a fish, and his memory returns.

It is obvious that the story of Shakuntala in itself is not very complimentary of her in terms of establishing a corpus of strong, independent Hindu womanhood, but it nevertheless offers all kinds of powerful suggestions for a foundational myth of Hindu India. For instance, through its detour into the story of Bharata (of whom nothing much is known to merit a separate comic), it helps to confirm Hindu India's so called descent from a pure line of Aryan kings, with roots going back to Vedic sages and gods. So Shakuntala's story would seem to be merely a colourful story with which to introduce Bharata as our venerable ancestor. However, the blatant adjustments made to the original versions of the Shakuntala story reveal an ambivalence that has at its heart the pressing need to bridge the gap between the traditional feminine ideal and sexual aspirations of modern Indian women. One way of doing this is to set up these ancient goddesses, nymphs and classical heroines as being totally unfettered, in movement and thinking. But this lack of inhibitions or fetters is only available to the upper caste Vedic women. It is paradoxical that while the distinction makes them exceptional, licensed to freedoms that are not allowed to their lower caste sisters for instance, this exceptionality poses no restriction to them being used in an exemplary way, as models for emulation. ${ }^{4}$ How is this achieved?

10 Across the wide heterogeneity in the representation of women, there is one singular trait that defines them, which is that of voluntarism. Whether she is a sati sacrificing herself at the altar of her husband's funeral pyre-an incarnation of a female self-sacrificing principle-or a shakti, the female embodiment of power, wreaking havoc in the enemy lines, these two female embodiments are united in so far as they exercise what is fetishized as individual choice, translated as an emblem of female agency. However, the question before us is how the combination of reality effects, induced by the clever deployment of the tactile aura of oil painting' that opens up 'for a mass clientele a novel mode of entering and possessing the pictorial image' (Guha Thakurta 1991: 97), and of the 'commodification of women' and 'tropizing of the feminine' (Uberoi 1990: 42) can bring about the agency result. In other words, what are the mediations through which the deceptive allure of the sexualized female body appears as a sign of empowerment?

The ACK's ideological position on women can be read off from the inside cover of ACK's Ranak Devi:

The status of women in India through the ages has been conditioned by social, economic and political factors [italics mine]. In ancient India, women were treated with respect. Although women had to look to men for protection, they did not have to live in seclusion. No restrictions were placed on their movements, nor were they denied the right to education. Gradually women came to be relegated to a position of little or no importance in society. In medieval India, where battles were fought frequently, the woman came to be confined to her house lest there be a threat to her person and honour. In spite of the precautions taken, there were instances of women becoming helpless victims of power politics-pawns in the ego games of rival kings. ${ }^{5}$

12 The allusion to the 'social, economic and political factors' indicates the unalterable hierarchy of the mythic world, where men hold the key to production, and women are granted freedom of movement and the right to education. The idea, it seems, is not so much to deny the existence of a pre-modern patriarchy, but to prove its superiority to 
the western model, and further, to suggest how the glorious Vedic past was thrown into disorder by the Muslim marauders in the medieval period. In the Vedic past, women not only had respect and autonomy, but they could also look to men for protection. The 'helpless victims of power politics' is, of course, a reference to the political marriages that were arranged between the Mughals and Rajput princesses. The entire passage is striking because it talks about the past in the language of bourgeois individualism, which allows the practice of sati to be articulated as the supreme act of the self. For instance, as Clarisse Bader notes, Savitri, Brahma's consort, not only 'identifies her life with her husband's... but her death with his' (Chakravarty 1989: 46).

\section{Amar Chitra Katha's Shakuntala}

The most distinct thing about the ACK women, and one that continues to resonate with the popular version of the emancipated feminine in other media as well, is their lack of inhibition, wittingly or unwittingly translated as sexual or libidinal freedom. This lack of inhibition ironically goes together with the signifiers of shyness and being demure. In Hindi films, for instance, the mandatory song and dance sequence around the tree involves the heroine in moves that reveal her body to be an extension of natural growth: vines, flowers, trees. The ACK Shakuntala is drawn precisely in this vein, her love of nature seen to be consonant with her freedom to love and choose a partner, her coy femininity adding to the free sexual vibes (Figure 1).

\section{Figure 1}

\section{SHAKUNTALA}

THE FORGOTTEN WIFE

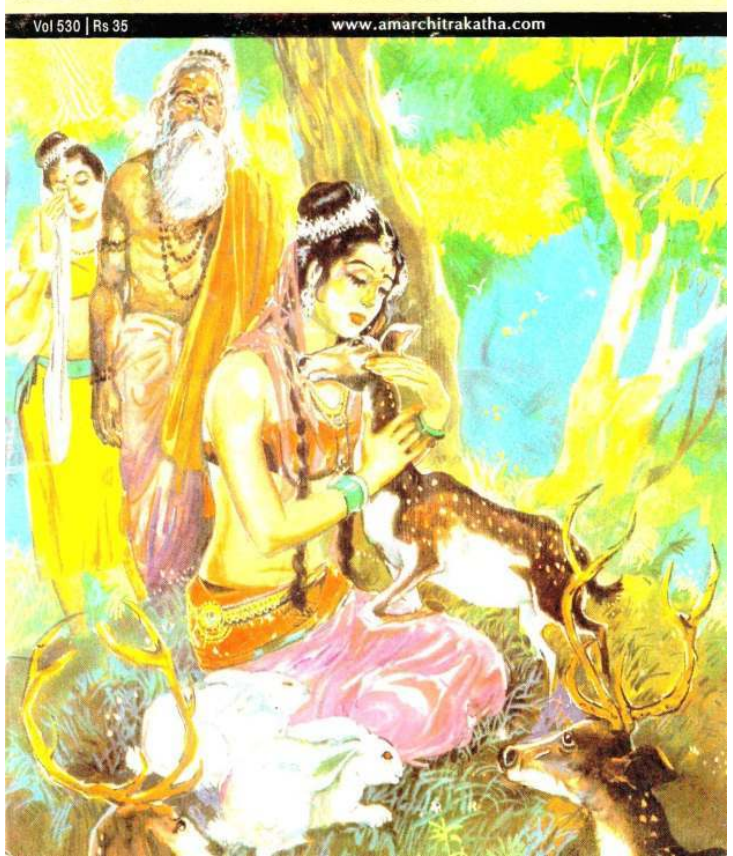

The emphasis on the sexualized and fantasized presence of classical heroines was able to deflect attention from the legitimized male predatory behaviour and the son preference bias of these texts, implying that nothing could be done to these women without their 
consents. Ironically, the extensive show of flesh and implied voluntarism also ushered in the spectacle of monogamous conjugality within a polygamous context. Whatever the undesirable connotations of classical women sun-bathing in the ancient sun, it seems that ACK was not too concerned with regulating the traffic in risque signals. Through a close reading of the comic Shakuntala, I will however try to engage with the conflicting traffic of meanings arising from the conscious and unconscious deployment of over sexualized women in $A C K$, and how that aided or inhibited the more pedagogic aim of creating female role models.

15 As remarked earlier, the ACK Shakuntala draws from what seems, at first, a completely arbitrary mix of the assertive Mahabharata figure and the more coy and feminine one in the Kalidasa play. But this seeming arbitrariness or eclecticism is actually mediated by the constraints of a middle class audience, which regards gender as a discrete and reified category, giving primacy to the sex of the class-, caste- and racially-marked body. In the case of Vedic upper caste women though, their beauty is so completely a signifier of their femininity that its gendered excess marks them typically as women of high and noble birth. The overwhelming beauty of the classical heroine is then marshaled in all comics in order to suppress all other markers of identity that might deflect attention from the fact that they are women and only women.

In Kalidasa's play, there are lots of references to the painterly quality of Shakuntala's beauty (Thapar 1999). With her head resting on her hand, she looks like a painting. The friends put the ornaments on her the way they have seen it done in paintings. When the king is suffering the 'Shakuntala disease', ${ }^{6}$ the only thing which distracts him from his anguish and remorse is the lifelike painting he makes of her, though in his view this fails to do adequate justice to the beauty of the real Shakuntala. However, the apsara (celestial nymph) Sanumati recognizes the visceral quality of the painting, and can see why the king might delude himself that the real Shakuntala is sitting in front of him. It is clear that beauty, in order to be effectively represented, has to be both still life and visceral, to conjure the illusion of a physical presence.

ACK chooses to interpret this ancient reference to the almost hypnotic and illusionistic quality of the beautiful in terms of the language of realism. Predictably enough, it assumes that this beauty can be rendered only through the most recent and valued $19^{\text {th }}$ century academic photorealism albeit in a bazaar derivative form. It must be remembered that under the long drawn project of conservation of the ancient Indian architectural art which started around the 1870s, the cave paintings of Ajanta had been copied out by students of the J.J School of Art (under Principal John Griffiths) trained in the academic realist style. The ancient style was valued above all for its perspective, shading details and foreshortening (Guha Thakurta 2004: 58). The painting of Shakuntala that Dushyant drew for a modern comic book audience was not however a realist mediation of an Ajanta-like drawing (Figure 2). ACK realism is de-historicizing, deliberately disavowing the historically determinate varieties of verisimilitude: the gods and heroes are not to be identified as figments of people's imagination in different historical epochs, but as actually representing real primordial gods and heroes. What is more, heroes and gods must be drawn with the same brush so that the godly/Aryan connection of Hindu humans is firmly and indisputably established. Shakuntala's beauty is then a product of this kitschy art form that developed in the mid- $20^{\text {th }}$ century south-western coastline, deployed to guarantee her divine ancestry. In other words, she is beautiful only to the extent that she has Aryanized godly ancestors. 
Figure 2

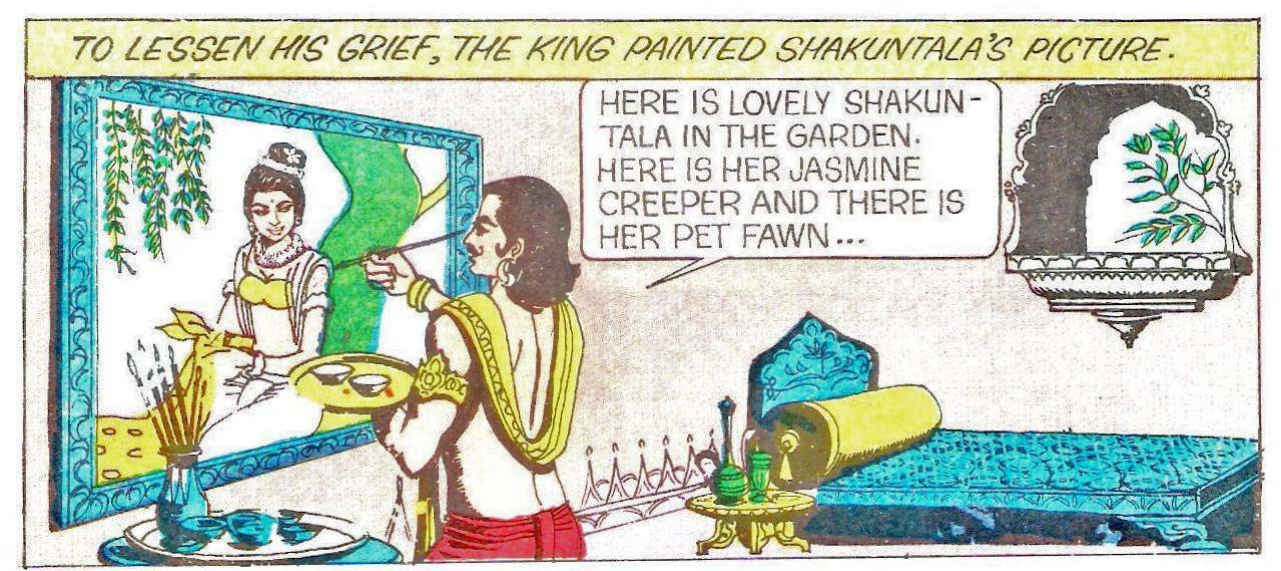

18 The fact of the Shakuntala title being the second in the series connects to this foundational Aryan imagination if we take the story of Shakuntala to be an origin myth of the land of Bharata, or the birth of Bharata, the founding Aryan father. Ironically however, the claim of a pure and continuous line of descent from Bharata downwards is compromised by the very realism ACK has adopted to tell its tale. This is because the Shakuntala comic was drawn by a Malayali (Malayalam speaking from the state of Kerala) artist K.P. Shankar (dates unknown), who couldn't help inflecting his heroes and heroines with a pronounced Malayali look and feel (Figure 3). The figures were stouter and more rounded, and generally they resembled the characters he was later to draw in comics exclusively situated in Kerala such as Techolli Othenan. This militated against the macrocosmology of $A C K$ where the south was characteristically the home of demons commonly understood as belonging to a Dravidianized ancestry. The north Indian physiognomy of the Aryans was in turn split into manavas (humans) and devas (gods) evident in the three part typology formulated by Ram Waeerkar (1936-2003?), ${ }^{7}$ one of the pioneering artists of the ACK pantheon. It is interesting that the illustrator Shankar was subsequently used only for Malayali titles as opposed to the mythological titles with their pan-Indian reach. In drawing the heroes from Hastinapur in this South Indian manner, he complicated the question of beauty to an extent. 

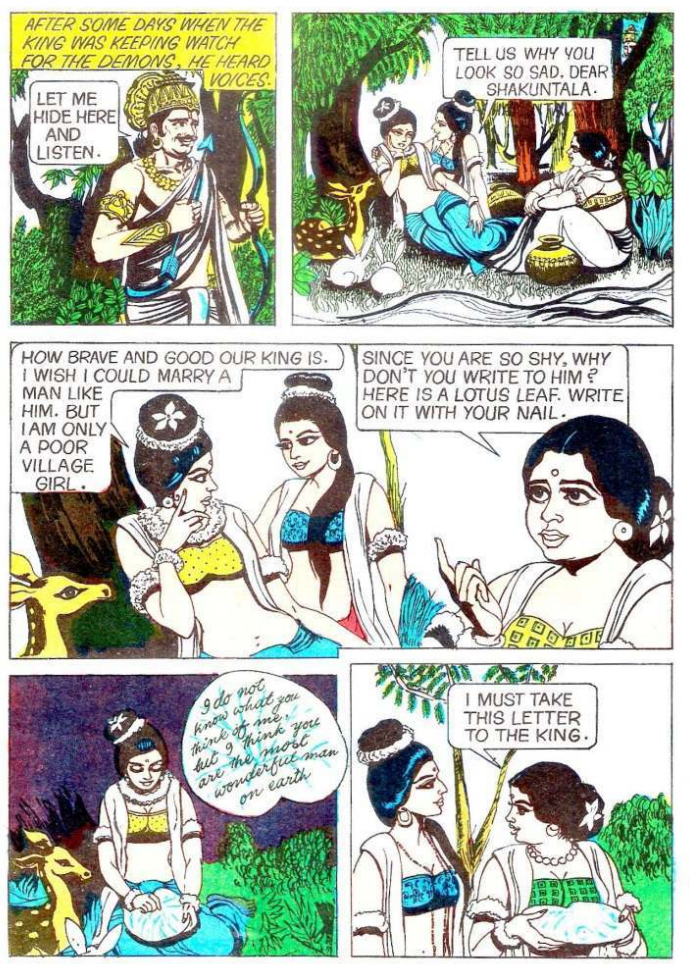

How do we understand the constituent elements of the concept of Aryan beauty? In the comic, demons appear in only one frame. They are painted green, obese, intended as grotesque (Figure 4), and in no way comparable to the fair-skinned protagonists, but the more intangible Dravidian features nevertheless lurk underneath the outlines of the nondemon protagonists as mentioned above. Is it adequate to differentiate the Aryan from the Dravidian simply through skin colour? What about other features? What do we make of the complicated history of assimilation brought about through the North Indian Brahmin migration to the south? ${ }^{8}$ To a large extent, the leitmotivs of $A C K$, its fixation on the south-western coast of the country, as a source of its stories, stems from the founder Anant Pai's origins in this Konkan belt. It is believed that the purest of the Brahmins namely the Saraswats and Namboodris had migrated to the south led by Parshuram (a Brahmin warrior) in a time coterminous with the mythological events (Chandra 2008: 27-84). Following this, it would seem that what is physiognomically identified as southern features in the present is therefore deceptive since it preserves features of the most hallowed North Indian genetic makeup, embodied in the purity of the purest south Indian Brahmins. But simultaneously, the idea of assimilation completely challenges the idea of purity. The painter Ravi Varma (1848-1906), the father of India's neo-realism in many ways, had already anticipated this in blithely drawing the Hindu noble pantheon with a Malayali look and feel, being a Malayali himself. The problem lies in the way this 'Malayali' look distributes itself between the Brahmins' nobility and the native population. 


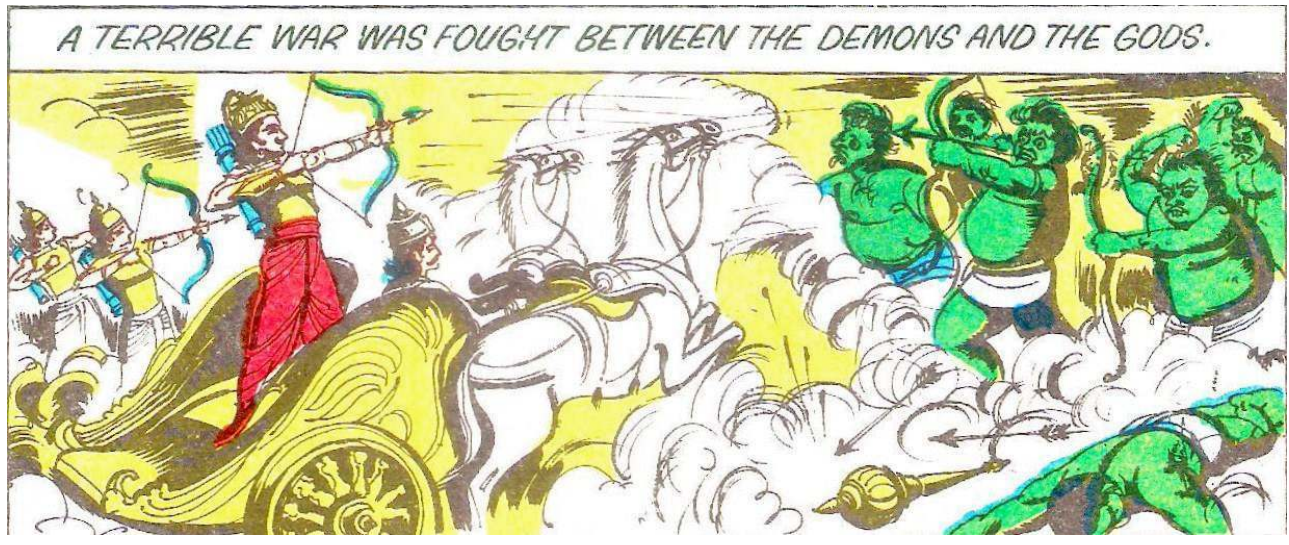

Generally, I have observed that the greatest innovation and flexibility was available to the artists in drawing not the Aryan heroes, but the non-Aryanized demons, tribals and Muslims. Since they did not fit into the protocols of a modular academic realism, the artists could be more experimental vis-à-vis their demon portraits. Some of the most vivid, visceral figures in $A C K$ are of the demon others (Figure 5). However, in this second title from the ACK corpus, the single frame devoted to the demons paints them in a hurried way as a blurred swathe of colours, betraying an uncertainty about their physiognomic contours. At the same time, Shakuntala, the quintessential Aryan belle, has to be drawn in a manner that will bring forth her full sensual potential. The vagueness of the demons testifies to an unresolved confusion over the particular schematic division to be deployed between the northern Aryans and southern Dravidians in ACK, fuelling contradictory resonances. For instance, like in the play, Shakuntala is chaperoned by her two female friends virtually acting as her hand maidens. Unconsciously perhaps, it is these two who have the pronounced Malayali look, the regional inflection highlighting their subordinate status. 


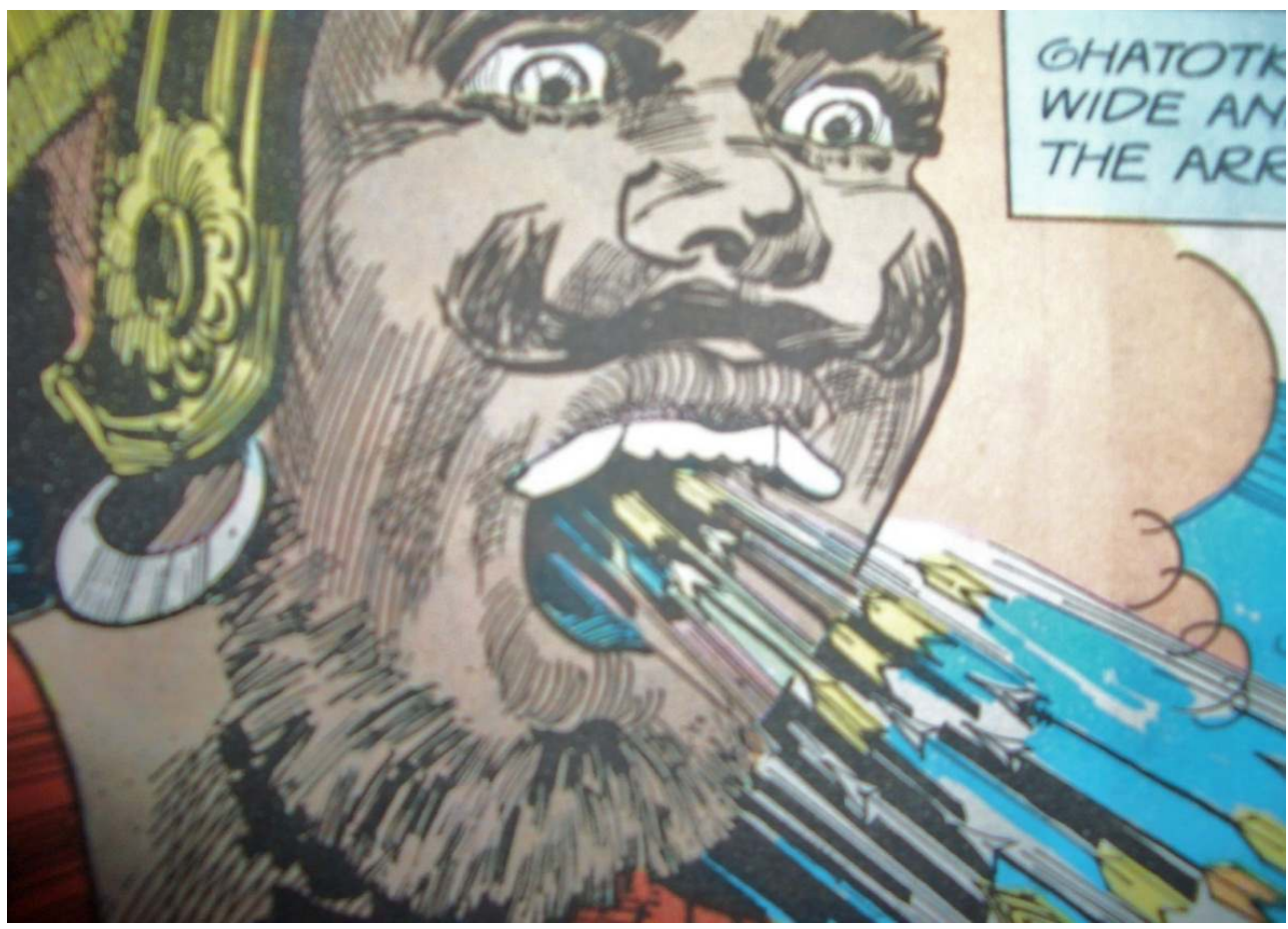

21 As the ACK series evolved, each and every aesthetic and editorial decision had to go through a series of conscious mediations in consideration of the dual interest of representing a remote historicized reality and presenting that reality in such a way that it had appeal for a middle class audience. For instance, Shakuntala's beauty foregrounded and embellished through an array of cinematic poses and angles seems to translate the coy and delicate feminine of Kalidasa into the Hindi film aesthetic of the saucy heroine (Figure 6). However, despite the oblique flirtations and dainty airs, we are completely taken by surprise when she proposes marriage to Dushyant. That is neither the style of the classical nor of the Hindi film heroine. What do we make of this proposal within the contending romantic paradigms?

\section{Figure 6}

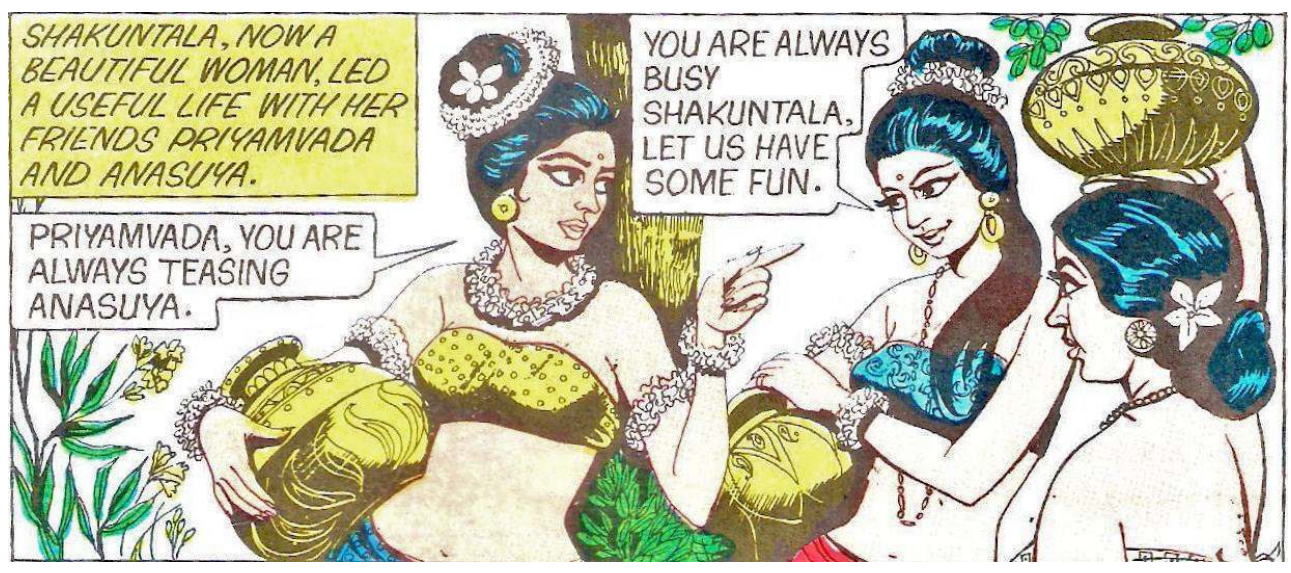

ACK's attempt to appropriate the classical romantic genre strove to relocate the romance from a heroine-centred narrative to one firmly focused on a nationalist imaginary. The 
national romantic was interested in demonstrating the freedom of the Indian woman within a broadly patriarchal set up. In tandem with the insidious mechanism of the comic mode, while the trope of the free woman was etched with much fanfare, the larger patriarchal frame was constructed through a more veiled negotiation of words and images. It was not easy after all to openly avow the potentially censorious elements of the story like sexual openness, polygamy and son preference. How would ACK craft a nationally appropriate romantic narrative out of antique erotic tales (as in the Mahabharata) where the kings' sexual predatoriness and the woman's devaluation, after she has fulfilled the ritual obligation of providing a male heir, are taken as casual facts? Kalidasa's Shakuntala offers a dramatic mediation of this realist world view in so far as it dilutes the hero Dushyant's intransigence by inserting the drama of enforced forgetting. We can begin by seeing how Anant Pai translates this into the still modern format of the comic and his vision of a scientific mythic universe.

the erotic ravishment of the heroine, and to that extent they were distinct from the modern romantic genre which is more about the exploration of a feminine subjectivity. This feminine subjectivity may include the ravishment motif, but if we were to take Janice Radway's (1991) study of the modern western romance, the context of that ravishment is intended to overcome the fear of rape or address issues of nurturance and care that are not fulfilled within the heterosexual patriarchal marriage. Ultimately, the function of the romance is to assure the women readers of the desirability of committing to a monogamous bourgeois marriage (Radway 1991: 214). The female as reader, and consequently what she feels, is thus the core of the modern romantic moment. In contrast, female subjectivity does not occupy such a central place in the classical romantic genre.

It is fairly well known that Kalidasa's Shakuntala is a significant diminution of the Mahabharata's Shakuntala in terms of assertiveness and independence. Nonetheless, Kalidasa preserves certain useful attributes of Shakuntala's individuality in so far as it supports the romantic plot structure. The ACK Shakuntala, although based on the Kalidasa play, completely erases any signs and dilemmas of the romantic narrative as it straddles the pre-bourgeois and the bourgeois culture. Generally in ACKs, all romantic nayikas (heroines) are visually alluring and ravishing in the tradition of the Sanskrit canon, but the comics edit out the most minimal subjectivity needed to maintain the romantic tension in any productive way. The apsaras (heavenly nymphs) are glorified seductresses. Virginal romantic nayikas like Vasavdatta, Ratnavali and Shakuntala (Figure 7) are comely, but their sexuality is robbed of any threatening potential that a more substantial selfhood would grant them. On the level of the romantic discourse culled from the original sources, one knows these particular romantic nayikas are not threatening because they are fervently committed to their lords and masters irrespective of their multiple wives, and despite the awareness in most cases that their amorous life is going to be short lived compared to that of their husbands. The ACK text does not provide us with the relevant information. At the level of imagery, therefore, one is hard pressed to understand why despite being drawn in evidently pin-up exposure mode, they don't violate the ethic of Hindu modesty. What prevents classical heroines being illustrated as pin-up models from affronting upper caste Hindu sensibilities? Is it sufficient to argue that all women in ancient times dressed skimpily? 


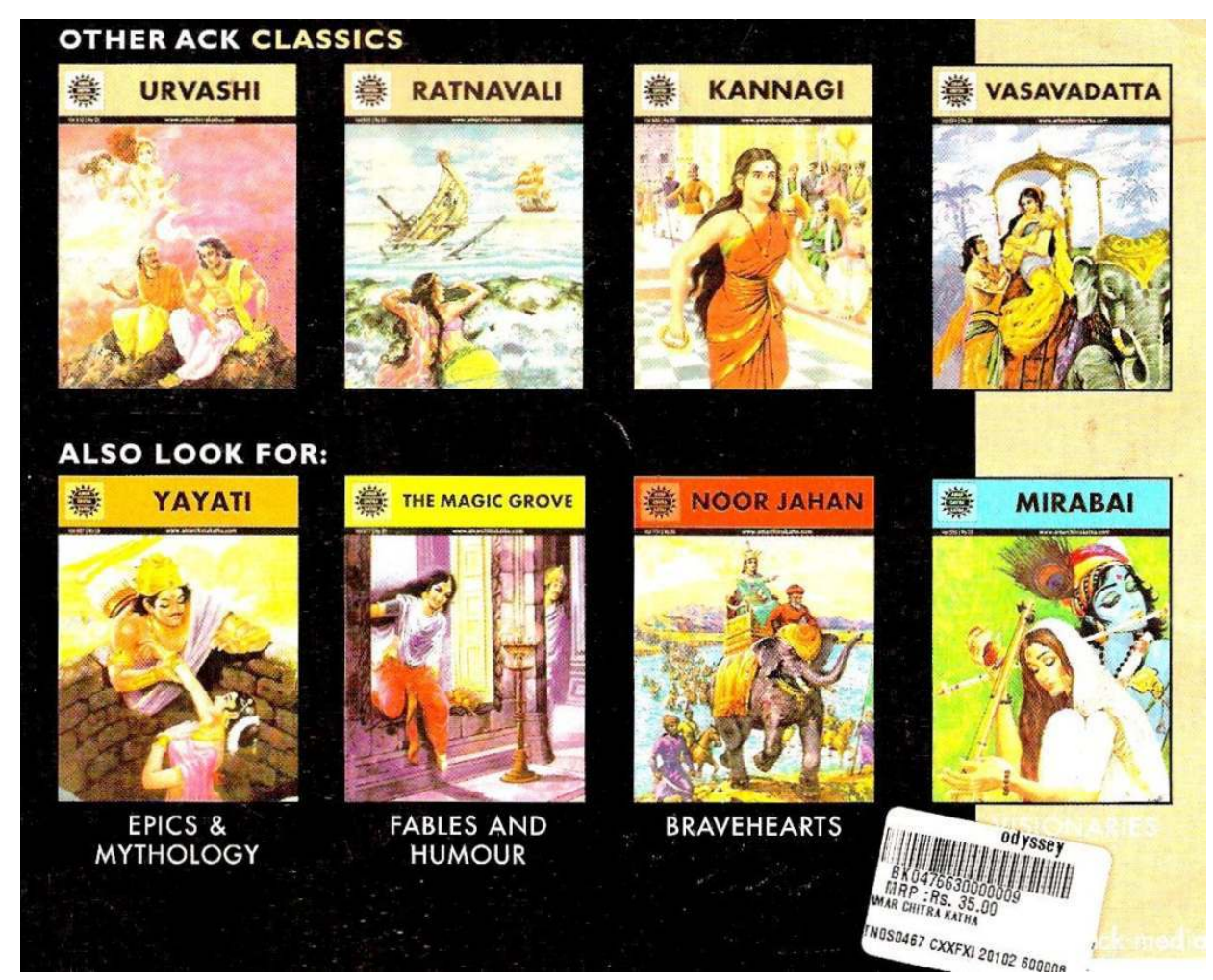

The ancient women if at all threatening are so on account of other reasons such as the conditions they might attach to the marriage contract. For instance, Satyavati, the fisherman's daughter in the comic Bheeshma who catches the eye of Shantanu, agrees to the union only on the condition that her future son be made heir to the throne. To a degree, even the romantic nayika and the comely apsara are known to have laid down conditions before a union, to suggest that marriage was more a contract than a sacred bond. In any case, the important point is that classical romance operated within a deeply materialist paradigm, well attuned to the ruling needs of sex, legal status and rights, kinship rules and reproduction. The same cannot be said of the modern genre which by definition is defiant and necessarily seeking to escape the social constraints indicated by these needs. Ironically, it is committed to the understanding of love as a sacrament and an escape into a personal utopia. Thus, if $A C K$ were to play up the contractual nature of the pre-bourgeois romance, it would invariably risk flattening out the romantic strains in the modern sense. Let us take a look at what ACK does with some of these 'non-romantic' tropes in Kalidasa's play.

Consistently throughout the play, Shakuntala's love is presented foremost as erotic desire - 'love violently tortures my limbs'. In the comic, however, the confession of desire and lust is completely sanitized as 'I do not know what you think of me but I think you are the most wonderful man on earth' (Figure 3) followed by an exchange of 'I love you' (Figure 8). This is followed by a flagrant violation of the content of both the Mahabharata and the Kalidasa versions. Shakuntala is made to propose marriage: 'Let us exchange garlands and marry as forest people do' (Figure 8). Both in the Kalidasa version and the Mahabharata version, she actually hesitates to give in to the king's amorous advances and asks him to control his passions. In the Mahabharata version, there is not only no initiative taken by Shakuntala to consummate her marriage, but she also draws up a pre-nup, as it were. She 
agrees to sleep with him only after he has pledged to make their future son heir to the throne. Obviously, she has some idea about the other wives. The ACK investment of sexual assertiveness stands out oddly considering there is nothing else to suggest that the woman has any initiative. Nor does it add to the romantic pitch of either the courtly or the modern contexts. In both traditions of romance we are considering, women are to be taken forcefully rather than shown as initiating sex. Their libido is confined to the presentation of a nubile self.

27 I can only think of the following explanation for the ACK transgression: the risk of presenting the king in a hurry to ravish shakuntala would foreground his predatory nature, not tolerable in a national-popular hero. But even worse is the prospect that Shakuntala could actually plead or command the king to exercise restraint. Her eventual consent could also make her appear character-less or as a shameless woman, as someone negotiating sexual contact, not appropriate again in someone projected as the mother of the Indian nation. The best option then was to allow her to initiate the gandharva marriage (contracted by mutual consent without formal rituals) and make it appear part of the ethnography of ancient forest people, something that they customarily do.

Figure 8
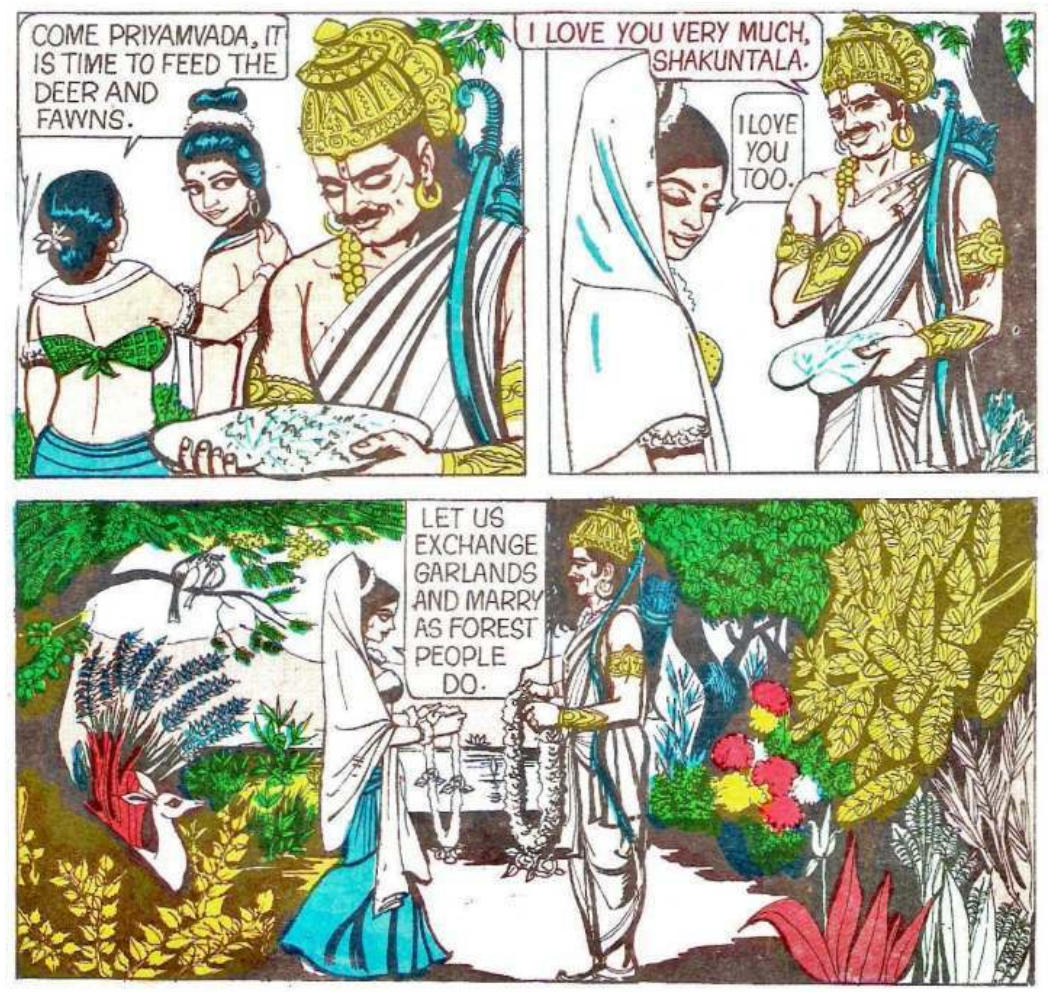

In continuation with the erotic ravishment of the heroine, the play repeatedly emphasizes the virginity of Shakuntala as 'a flower no one has smelled, a bud no fingers have plucked... honey untasted, unbroken fruit of holy seeds' and the thrill of savouring virgin flesh. There is also repeated mention of the many wives, and the sorrow and jealousy of at least one wife who is lamenting the transience of her romantic liaison with the king (Hamsavati's song reproaching her husband for new loves). Then there is the fear and foreboding of Shakuntala's friends who are afraid that the king is merely using her as a play thing and will discard her: 'We have heard that kings have many loves. Will 
our dear friend become a sorrow to her family after you have spent time with her?' Similarly, the wise people, the ascetics, all advise Shakuntala to be patient with the king's occasional harshness and be friendly to the co-wives. All these elements are an indication of how for the woman in love, the expectations are really modest. As the play proceeds, we see that the fear of her friends is of course confirmed but the counsel of her elders ignored as Shakuntala loses her cool in the face of the king's loss of memory, attesting to the fact that there is more to her than the pre-stipulated codes of femininity. Indeed, women are acknowledged as the signifiers of a different moral economy as evident when Dushyant expresses his revulsion for hunting provoked at the sight of the gentle Shakuntala ('the thought of hunting disgusts me when I see Kanva's daughter').

But apart from gesturing to women's alternative moral economy, the play completely confirms the fears surrounding the sexual use/abuse of the romantic nayika. It shows the king behaving in a rather sneaky way vis-à-vis his other wives. He is afraid of the palace women finding out about his passion for a forest maiden. He lies to the buffoon (a figure totally omitted from the comic) lest he reveal his guilty secret to them. On the other side, Shakuntala's friends are afraid of Kanva's reaction to the lovers' indiscretion, and are surprised that he is not angry, all pointing to the fact that the gandharva option was not as acceptable as it is made out to be in the comic version. Shakuntala exercises caution even when consumed with desire. She wants a formal sanction of the union either through her elders or friends. It's not a private decision, whereas the king would rather like it to be clandestine and immediate. The gandharva option is definitely not something that is encouraged. The sage Kanva and the elders (like Gautami) repeatedly refer to the fact that Shakuntala's kinsmen had not been consulted in the haste with which the king married her, euphemism for the force or rape that is a staple of romantic literature. The $A C K$ version, however, removes all traces of this ambiguity and tension, whether it is the elaborate debates around the decision to go for a gandharva union or the tension surrounding the polygamous context of the romance. The fact that classical romance recognized that the needs and rights of women within marriage were far from assured, but had to be secured through a system of conditions and provisos, is of course elided in the comic.

When Shakuntala is leaving the forest in the play, part of her grief stems from the knowledge that she will not be coming back any time soon. But in the comic, she is shown as confidently consoling her friends by assuring them about her frequent visits back home: 'I will come to meet you often' (Figure 9). In the play, when Shakuntala asks Kanva if she will ever be able to return to her original home, he tells her that once their son takes over the reins of the kingdom, the two will be free to surrender their worldly bonds and return to the hermitage. The ACK narrative shears this implicit exile of the female ascetic implied in her surrender of the forest life. The need to present marriage first and foremost as a humane and kindly institution, which allows women to maintain close contact with their paternal homes, is meant to blunt the cruelty and alienation implicit in patri-local residence. 

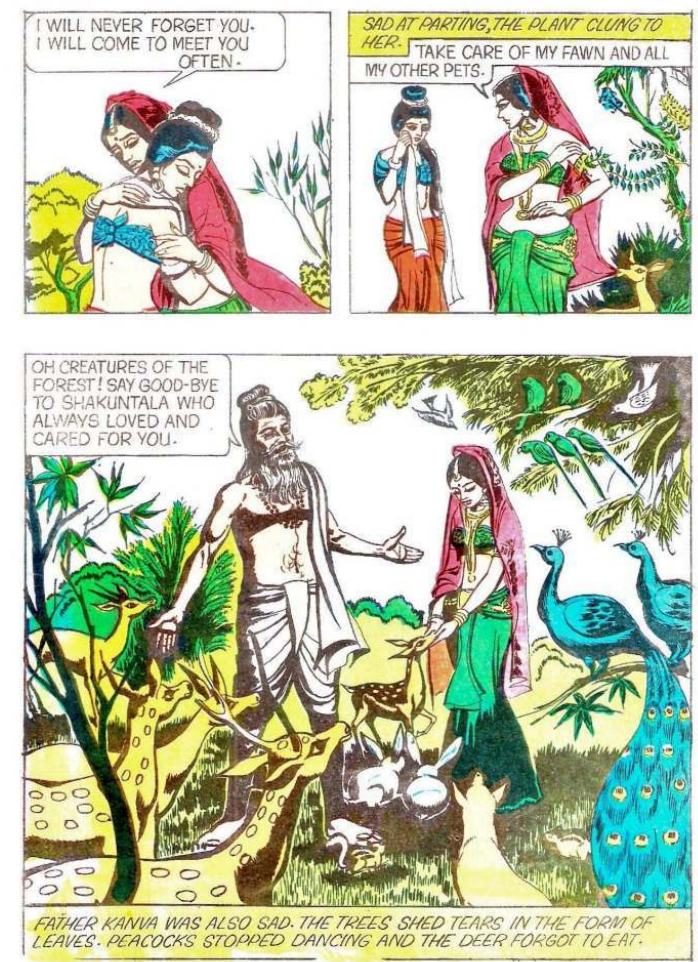

Perhaps anger at the hero's callous and cruel behaviour is the only element common to both traditions of romance, ancient and modern. This may be because it allows the man to be fully vindicated once the misunderstanding or deception involved in his behaviour toward the heroine has been resolved. In the bourgeois context, the anger also allows the women to vent out feelings that are generally suppressed under the construction of women as soft-spoken and gentle. In the Kalidasa text, it allows Shakuntala to allude to the potential arrogance of the king: 'evil man, you see everything distorted by your own ignoble heart'. Also, her anger does not either spare her escorts from the hermitage when they decide to abandon her: 'Am I deceived by this cruel man and then abandoned by you?' of course, the absence of anger in the comic prevents any critique of kingly power or of the unfair rules of patriarchy. Instead we are made to see an abject woman, her emotions directed not so much at the king's deception and falsity but at the fact of her victimhood. Most significantly, her back is turned on the readers when she says the only harsh thing to him: 'Oh Dushyant! It is wicked of you to disown your wife' (Figure 10). Also, her addressing him by name rather than as Noble King/husband or Puru King (as in the source texts) is suggestive of an intimacy that is not only anachronistic but also allows the comic to cater to its bourgeois audience's need for a false semblance of equality in conjugal relations. The abandonment by her kinsmen is not allowed to sink in fully either, since the sage at the court instantly adopts her so that it appears that she has not been forsaken entirely. After that, the narrative comes to a speedy enough conclusion with Dushyant begging forgiveness, and reiterating the promise of a happy married life. 


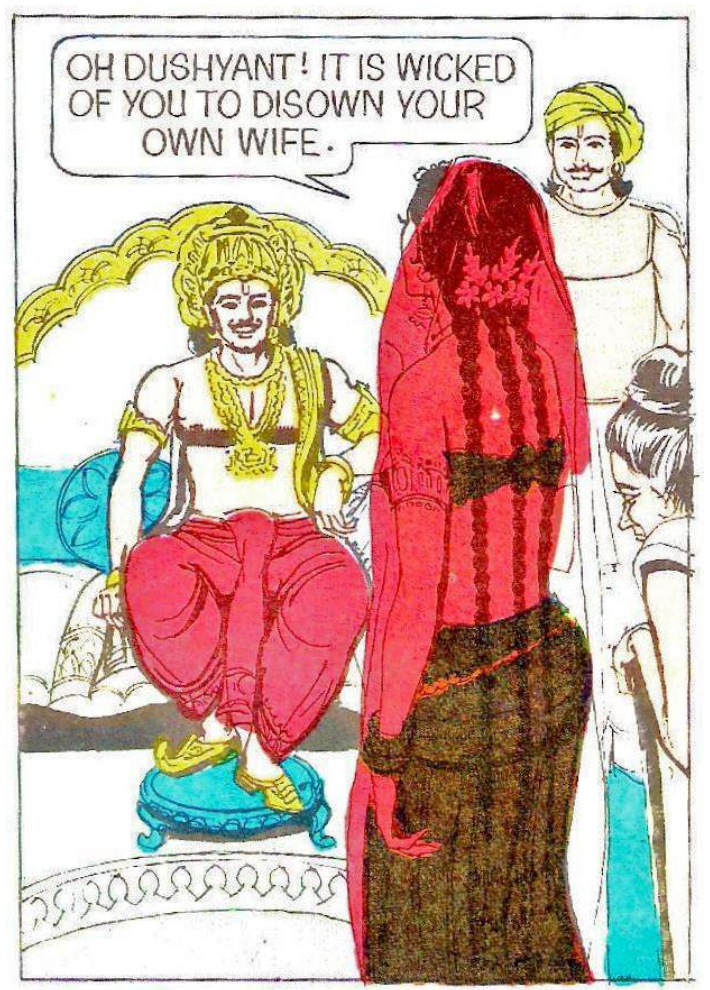

The flattening of the romantic narrative, making the king totally blameless from the start so that there is no anger at his misdemeanour, ensures that there will be no pleasure at his remorse later. After all, there is no apsara Sanumati in the comic to take pleasure in the king's remorse and suffering, or to appreciate Shakuntala's pining for a husband who ostensibly disgraced her. What is more, the narrative divests the heroine of all but one instance of agency, the initiative in proposing to the man, which undercuts the romantic tension even further. Even in her relationship to nature in the hermitage, the tenderness that she is famous for is turned around so that it is the birds, animals and trees that cling to her and feel the pangs of parting, not she. She is shown too busy consoling them. Her grief is on account of their grief.

Similarly, the comic accentuates her lost, absent minded profile, not worldly enough even to register the curse or take care of the ring. It is true that, even in the play, her friends do not let her in on the mystery of the curse so that she is ignorant of why her husband refuses to recognize her. But the play provides the context for this special pampering of her fragile ecology ('our friend is fragile by nature; she needs our protection/who would sprinkle a jasmine with scalding water?'). She is also 'the breath of Father Kanva's life', and she is sick. A heat stroke can be a serious affair. But in the comic, without the requisite explanation for this sheltered self, she seems like a case study in feminine distress (Figure 11), not the assertive ACK ideal. 


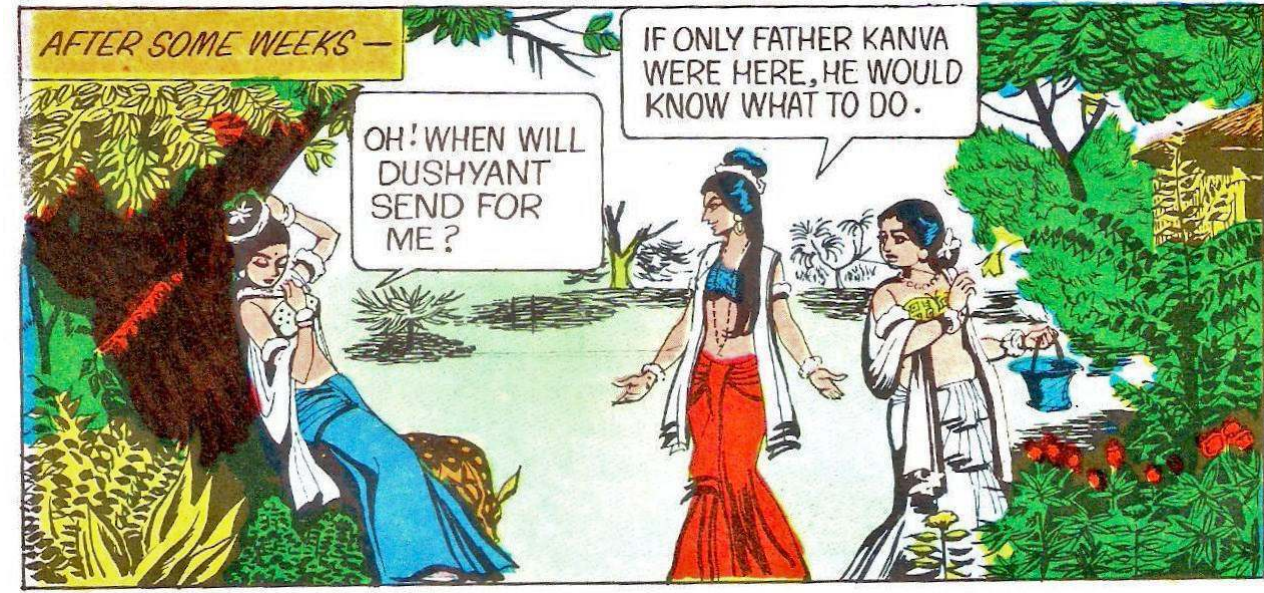

It is almost as if ACK was experimenting with different models of femininity. Shakuntala seemed a good example to inaugurate the long tradition of über-feminine Hindu women, not least because she is Bharata's mother and by implication the mother of the Aryan race. However, in retrospect she turns out to be quite an atypical heroine - naive and clueless. The text steadily strips her of her sensuous charms enacted through Hindi film expressions and gestures, turning her into a docile indifferent figure. The forest scenes of romance soon give way to a more regulated appearance, defined by ornaments, drapes and veils (Figure 12). Thereafter, the close-ups too give way to mid and long shots, so that the sexiness is literally not in your face anymore (Figure 13). But through this blurring of boundaries between the courtly feminine and the creature of the forest, she ends up confirming the ACK archetype of the ancient heroine most pertinently, as both naturally alluring and implicitly noble. Perhaps, this is what the ideal of the ACK heroine is supposed to represent, a domestic goddess after her token autonomy has been established in a token way. 
Figures $12 \& 13$
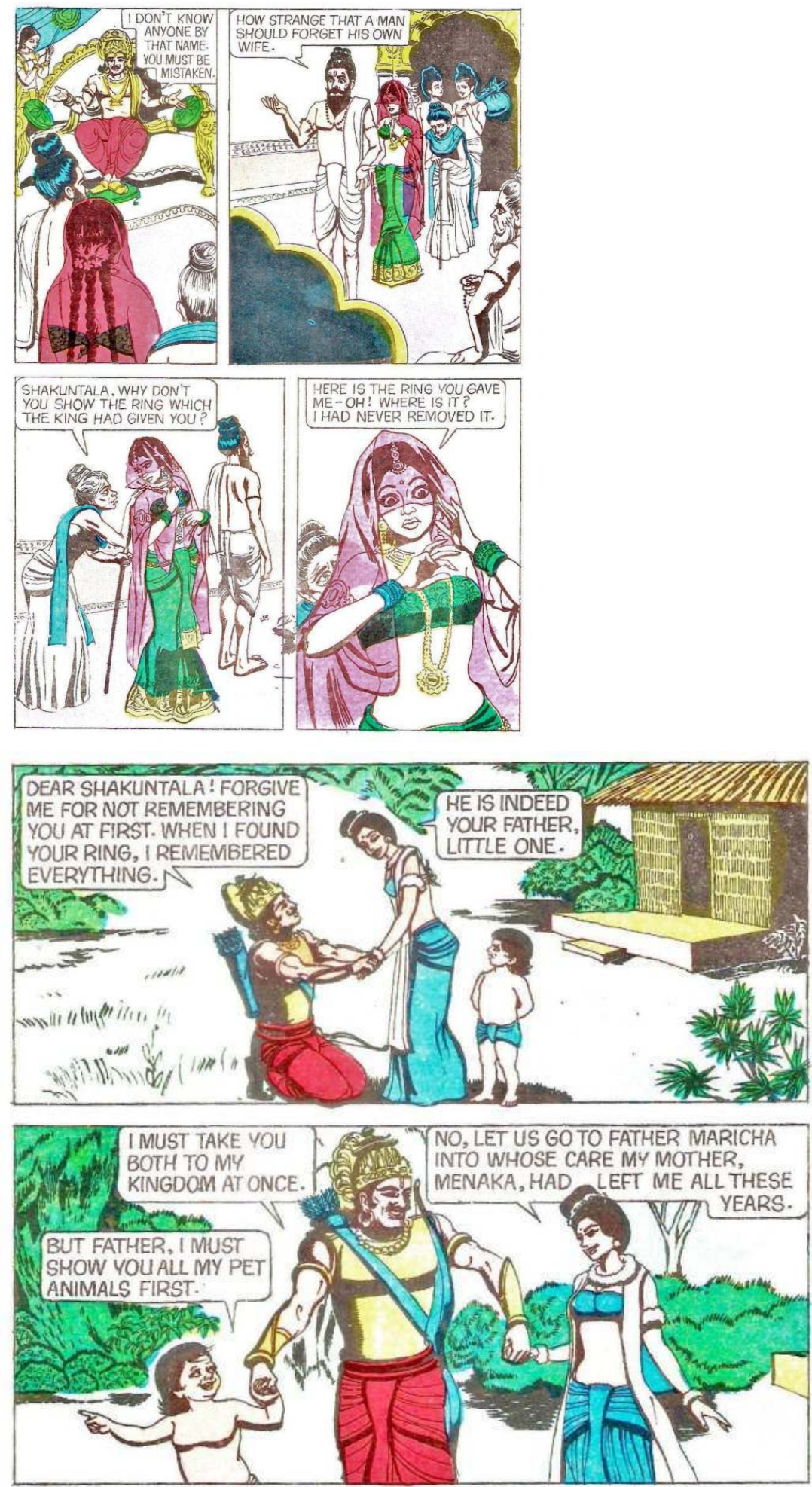


\section{Continuities between popular culture and contemporary judicial perceptions of women as sexual objects}

The strong tradition in Indian popular culture of romantic narratives within a marital setting is perhaps a pointer to the social fact of inaccessibility to the other sex in all but caste guided familial/familiar situations. ${ }^{9}$ Similarly, the ending of the traditional romantic story not so much in consummation or a kiss but the birth of a male child highlights the overlaps between romantic and reproductive sex. The effort to reconcile pre-modern romantic expectations with modern ones is not as far-fetched or difficult as one originally supposes, based on abstract notions of epochal changes. Despite the intrageneric differences across ages and cultural contexts, what is really problematic to the ACK patriarchy in the source texts is the representation of the hero Dushyant as a promiscuous and pleasure loving man, since this has immediate ramifications for how female ravishment is to be construed.

While it is true that male predatory behaviour is a punishable offense under a liberal regime which acknowledges the so called rights of women, the popular cultural sphere is full of stories of the celebration and tacit acceptance of such ravishment. Under the Indian Penal Code, the rape laws have more or less continued with the colonial definition of rape as 'outraging' the modesty, chastity and honour of women rather than an act of violence on their dignity, equality, sexual autonomy and bodily integrity (Kashyap 2010: 10). The passive submission of the woman in intimate domestic situations then becomes a pretext for acquitting the offender since it immediately delinks the violence from the honour or modesty motive, which can only be done by an outsider. ${ }^{10}$ Also, cover ups are a routine part of an alternative discourse in which the police habitually refuse to register FIRs (First Information Reports) of rape and sexual violence, especially if the accused happen to be persons of influence and authority. Not only that, the law enforcement agencies and politicians are known to bend over backwards to protect them and their reputation, very often by undertaking vicious slander campaigns against the rape victim, insinuating that she must be a woman of easy morals. ${ }^{11}$

The ACK Shakuntala story is striking because in its over-eagerness to protect Dushyant from the slur of being a sexual offender, it actually compels us to explore the possibility of the story as a rape and run narrative, what in American parlance would constitute a " date rape'. This focus becomes particularly resonant given the recent judicial interrogation of the existing rape laws which neither define nor exhaust all kinds of sexual assault undergone by women. The proposed Draft Bill on Sexual Assault 2010 also seeks to examine the definition of consent enshrined in section 375 of the Indian Penal Code. For instance, the mere absence of resistance or the presence of submission is not deemed an adequate definition of consent. Only unequivocal voluntary agreement by the person would constitute consent. ${ }^{12}$ Under the Victorian penal clause, consent is only envisaged when the woman is deluded into believing she is married to the man or her consent is given under the promise of marriage, as is the case with shakuntala. A woman who is not married has no business giving consent. The biggest positive outcome of this amendment is the recognition of consensual sexual relations outside the paradigm of marriage.

South Asia Multidisciplinary Academic Journal, 4 | 2010 

charge of her accusation against Dushyant rests precisely on the promise of marriage. Shakuntala's petition as a mother of a son trying to find justice in her husband's court is eerily reminiscent of the unwed mother narrative of Hindi films. ${ }^{13}$ To that extent, young readers would invariably derive from the story an understanding of consent exclusively and implicitly in monogamous or marital terms, and in turn of love within the very same hetero-normative boundaries. True to their modern romantic logic, Hindi films are at least willing to incriminate the hero for his irresponsible and predatory behaviour, if only to restore his manliness once he has made amends..$^{14}$ But $A C K$, it seems, will not incriminate the hero at any cost. It would much rather risk having the nayika's premarital sexual openness read as a sign of loose morals.

Within an overall framework of globalization, and the attendant shift in the class character of the various actors entering the media industry, one is less likely to view the risqué projections of item girls and sexualized pin-up models and actresses as an index of desperate socio-economic circumstances, something they are coerced into. On the contrary, the fact of their gratuitous self-commodification and objectification is taken almost for granted. It is autonomous of the logic of capital and completely explained in terms of individual choice. While ACK heroines cannot be seen quite through the same lens-since they are not actresses and as such not real individuals but drawings, sketched by male artists for a commodity driven market (albeit a more restrictive one)-, the libidinal postures they are sketched in are not simply designed to invite the male gaze, but denote a similar consensual frame of reference. The pseudo-subjectivity constituted by the eclectic mix of coy and assertive is then instrumental in achieving the affect of a stereotype-defying emancipated female subject.

But even when this pin-up model is bursting with autonomy and self-will, it fails to become a genuine role model. The comic eventually ends on the sad note of domestication, for the sexualized creature is totally diminished. This is not merely a paradox, but also the intrinsic aim of the bourgeois patriarchal project which seeks to constantly neutralize and render undesirable any aspiration toward the creation of female role models. In fact, being a role model is synonymous with an exceptional class or elite status. In other words, only women who are exceptional in terms of their social stature can be exemplary. ${ }^{15}$ What goes in the name of creating a canon of strong independent Hindu women is not strong independent Hindu women, but strength as membership to the dominant group or class. It is Shakuntala's high Vedic lineage which is remarkable and the reason for her iconization. But how can readers emulate high Vedic lineage? What young girls can emulate instead is her helpless coy femininity. Bharata, the illegitimate son, through his consecrated position as the founder of Bharat or India, is able to repudiate any illicit associations of the union that leads to his birth. In a homological association almost, Shakuntala's helplessness stands translated as a shorthand for active female consent!

\section{Conclusion}

41 To sum up, a 'selective tradition' constituted by a dominant ruling class or group is about the past only in so far as it 'is intended to connect with and ratify the present' (Williams 1977: 116). The glorious Hindu past of gorgeous and independent Aryan women then seeks to address anxieties about women's sexuality and independence in a modern

South Asia Multidisciplinary Academic Journal, 4 | 2010 
secular democracy. The problem is posed in terms of the increasing difficulty of imagining women as role models at a time when Hindu patriarchy, organized around stable caste hierarchies, is exposed to serious threats. The Shakuntala story resonates precisely because it depicts the destiny of a woman at the juncture of such a crisis (the absence of her father or of Dushyant). The story operates virtually like a veiled threat: if the patriarchal structures are not restored, the only other way women can become autonomous is through the tautological move of taking on the entire onus of their lives on their slender shoulders. Only under the condition of entering the full logic of bourgeois voluntarism, where their individual autonomy is the only motor governing their lives, can their elevation be considered.

The recent Virgin Comics combined venture between Shekhar Kapur, Richard Branson and Deepak Chopra-a collaboration of different global animation and comic styles-, illustrates the fashionable attractiveness of this principle of voluntaristic empowerment most evocatively, through indigenous superwoman titles like Devis and Snakewoman. Devi, for instance, is an incarnation of Shakti (dubbed the 'female aspect of the divine'), who takes the form of a modern young girl to fight crime in the city. The promotional trailer shows her as a goddess descended to earth, turned out in tart outfit, naked for the most part except for some thunderbolts covering her modesty. In a Star Wars-style intergalactic battle, she fights off strange evil creatures, thus highlighting the pathos of the lone woman ranger, who in order to be a hero must fight alone and who, if she must fight, is condemned to isolation.

Zvelebel, Kamil V. (1992) Companion Studies to the History of Tamil Literature, Leiden: E. J Brill.

\section{BIBLIOGRAPHY}

Chakravarti, Uma (1987) 'Whatever Happened to the Vedic Dasi: Orientalism, Nationalism and a Script for the Past' in Kumkum Sangari \& Sudesh Vaid (eds.), Recasting Women: Essays in Colonial History, Delhi: Kali for Women, pp. 27-87.

Chanda, Ipshita (2003) Packaging Freedom, Feminism and Popular Culture, Kolkata: Stree.

Chandra, Nandini (2008) The Classic Popular: Amar Chitra Katha (1967-2007), New Delhi: Yoda Press.

Friese, Kai (2010) ‘White Skin, Black Mask', Outlook, 20 March, URL: http://

www.outlookindia.com/article.aspx?264696.

Guha Thakurta, Tapati (1991) 'Women as 'Calendar Art' Icons: Emergence of Pictorial Stereotype in Colonial India', Economic and Political Weekly, 26 (43), pp. 91-9.

Guha Thakurta, Tapati (2004) Monuments, Objects, Histories: Institutions of Art in Colonial and Postcolonial India, New Delhi: Permanent Black.

Kapur, Shekhar (2006) Devi (promotional video), URL: http://videosift.com/video/Virgin-ComicsPresents-Shekhar-Kapurs-Devi.

Kashyap, Aruna (2010) Dignity on Trial: India's Need for Sound Standards for Conducting and Interpreting Forensic Examination for Rape Survivors, New York: Human Rights Watch. 
Lutgendorf, Philip (2010) 'Philip's fil-ums: Notes on Indian Popular Cinema', URL: http:// www.uiowa.edu/ incinema/RamTeriGM.html.

Majlis-e-Mashawarat (2010) Shopian: Institutional Denial of Justice, Srinagar: Majlis-e-Mashawarat.

Radway, Janice A. (1991) Reading the Romance: Women, Patriarchy, and Popular Literature, North Carolina: The University of North Carolina Press.

Sangari, Kumkum (1990) 'Mirabai and the Spiritual Economy of Bhakti', part 1, Economic and Political Weekly, 7 July, pp. 1464-75.

Sen, Rukmini (2010) 'Law Commission Reports on Rape', Economic and Political Weekly, 14 (44), pp. 81-7, URL: http://beta.epw.in/newsItem/comment/188925.

Thapar, Romila (1999) Sakuntala: Texts, Readings, Histories, New Delhi: Kali for Women.

The Tribune. 2007. 'Consensual Sex is not Rape: SC', 31 August, URL: http://

www.tribuneindia.com/2007/20070831/nation.htm\#9.

Uberoi, Patricia (1990) 'Feminine Identity and Nationalist Ethos in Indian Calendar Art', Economic and Political Weekly, 25 (17), pp. 41-8.

Williams, Raymond (1977) Marxism and Literature, Oxford: Oxford University Press.

\section{NOTES}

1. Phantom, one of the first costumed superheroes conceived by the American Lee Falk, first appeared as a newspaper comic strip in 1936. While it received moderate success in the US and no success in the UK, Falk is supposed to have made his fortune in the outlying colonies, from Australia and India to Sweden and New Zealand. However, it never made it to the darkest jungles of Africa where it was situated. For a personal memoir of the comics, see Kai Friese (2010: §8).

2. The Mahabharata is one of the two major Sanskrit epics dating roughly to the late BCs and early ADs, starting with a heroic bardic core and eventually consecrated into the divine Bhagavata-Gita text. Kalidasa is regarded as one of the greatest poets and dramatists of classical Sanskrit dating to the $5^{\text {th }}$ century CE.

3. All references to the Mahabharata and to the Kalidasa version are from Thapar (1999) which has adduced the English translations of J.A.B. van Buitenen (The Mahabharata. Vol. 1, Chicago: Chicago University Press, 1973), and of Barbara Stoler Miller (Theater of Memory: The Plays of Kalidasa, New York: Columbia University Press, 1984).

4. For a detailed treatment, see Chandra (2008).

5. ACK, 132, 10 April 1977 (emphasis added). Ranak Devi was illustrated by Dilip Kadam (1952-).

6. The king suffered a curse which erased of his memories of Shakuntala. Once relieved of it, he starts looking for her.

7. According to Waeerkar, 'The local people in the South were the Dravidas. They were darkcomplexioned, thin and not very handsome. To them the migrants from the North appeared healthy, tall and fair complexioned, like God. That is why they say all the gods are in the Himalayas. Those in the Ganga plateau are the Manava. Deva, Danava and Manava are the three ganas (the three distinct species namely gods, humans and demons)...So while Deva referred to the migrated people from the north, settled in the Himalayas, manavas are the local people in the north and the rakshashas are the tribal people in the jungles of Vindhyas' (Chandra 2008: 80).

8. From the $5^{\text {th }}$ century onwards, as the South was opened to wet agriculture, and as southern kingdoms blossomed, northern Brahmins, regarded as prestigious, were brought down to officiate over courtly ceremonies. The Brahminization of the South also extended to myths such 
as that of the Parshuram Kshetra, and as such it is very difficult to ascertain the question of the Northern Brahmins' migration to the South in precise historical terms. However, a more established tradition of historians including Romila Thapar, Burton Stein, Clarence Maloney, Iravatham Mahadevan and Zvelebel have suggested that 'Tamil literacy and civilization diffused in a south-north direction' (Zvelebel 1992: 23).

9. Ipshita Chanda (2003) makes this point in the concluding chapter ('Scripts for the Future') of her book.

10. There are many instances of extremely horrific and sexist pronouncements on the culpability of the rape victim such as the following one given by a Supreme court bench: 'The apex court noted that if a fully grown up girl consents to the act of sexual intercourse on a promise of marriage and continues to indulge in such activity until she becomes pregnant it is an act of promiscuity on her part, and not an act induced by misconception of fact' (The Tribune 2007).

11. As recently as May 2009, serial investigations into the infamous rape and murder of two young Kashmiri women, Asiya Jan and Neelofer Jan, by security forces in Shopian brought forth the spectacle of this double legal bind which recognizes rape as illegal, and thus seeks to disprove it by denying the fact of sexual assault. The different investigating teams alleged the women had been drowned, and when forensic evidence pointed otherwise, the entire nexus of official bureaucracy from the lowest to the highest levels sought to fudge the evidence in order to protect the policemen while defaming the women as immoral (Majlis-e-Mashawarat 2010).

12. According to the Sexual Assault Bill Draft, Section 375 needs to be amended to read 'a man is said to commit rape... thirdly, with her consent, when her consent has been obtained by putting her or any person in whom she is interested, in fear of death or of hurt, or of any other injury'. The words 'or of any other injury' expand the scope of this clause to provide for situations of rape by persons in position of trust, authority, guardianship, economic or social dominance. These cases would include incestuous rape and other instances where the victim is totally dependent on the offender who is in a dominant position. See Sen (2010).

13. From B.R. Chopra's paean to the illegitimate child in Dhool ka Phool (1959) and to Raj Kapoor's Ram Teri Ganga Maili (1985), the paternity suit is a patented highlight of the Hindi film melodrama.

14. According to Philip Lutgendorf (2010: §5), who reads Kapoor's film as a Shakuntala myth, the film 'substitutes a weak hero for an erring one and introduces parental and family complications that further exonerate him, and it situates most of its heroine's humiliation during her long journey to the metropolis'.

15. Talking about the $16^{\text {th }}$ century female poet Mirabai, Sangari (1990: 1472) says the space created by and for exceptional women is restricted space and can be made to ratify the rule for ordinary women'.

\section{ABSTRACTS}

This article attempts to understand the pedagogical implications of Shakuntala as a female role model indicated by the prominence given to her character in the comic book series Amar Chitra Katha $(A C K)$. Most of the female heroines in $A C K$, invariably components of a mythological/ legendary universe, are marked by their feminine allure and beauty. What was the conceivable framework in which overtly sexualized women were allowed to be role models in ACK? How is this identification with beauty squared with alternative ideals of the glorious Hindu/Vedic 
woman as free and independent? How did ACK negotiate the free sexuality of the ancient heroine to produce a normative national narrative of Hindu women as free in a larger spiritual and social sense? How did it read and adapt the ancient story of the Mahabharata along with the Kalidasa play to address its largely middle class urban child audience? How did the glorified pre-modern romance between Shakuntala and Dushyant framed within a predatory male sexual gaze come to acquire such a deep resonance within a modern Indian romantic imaginary?

INDEX

Keywords: children's literature, comics, consent, India, modern appropriation, monogamy, pseudo-subjectivity, rape laws, role models, romantic heroine, shakuntala

\section{AUTHOR}

\section{NANDINI CHANDRA}

Lecturer, Department of English, Delhi University 